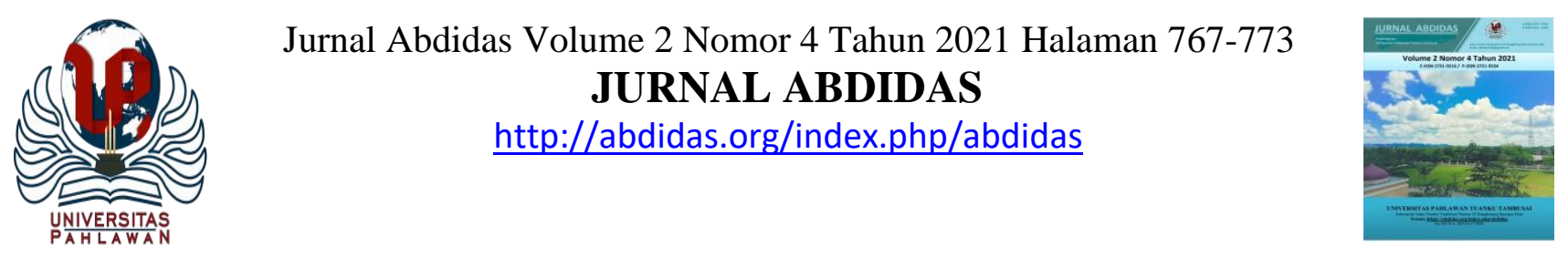

\title{
Meningkatkan Kompetensi Pelatih Pencak Silat Berbasis Sport Science Dan Tuntutan Aktifitas Pertandingan Pada Pelatih IPSI Se-Kabupaten Demak
}

\author{
Nur Subekti $^{1}$, Muhad Fatoni ${ }^{2}$, Rony Syaifullah $^{3}$ \\ Pendidikan Olahraga, Universitas Muhammadiyah Surakarta, Indonesia ${ }^{1,2}$ \\ Pendidikan Jasmani, Kesehatan dan Rekreasi, Universitas Sebelas Maret, Indonesia ${ }^{3}$

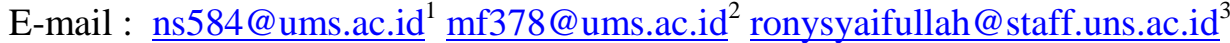

\begin{abstract}
Abstrak
Kegiatan pengabdian ini memiliki tujuan meningkatkan kompetensi pelatih pencak silat di Kabupaten Demak dalam pemahannya tentang dasar ilmu kepelatihan dan perencanaan program latihan. Kegiatan ini dilaksanakan atas dasar kerjasama antara pengabdi dan mitra (Dispora dan IPSI) Kabupaten Demak. Sebanyak 30 peserta berpartispasi dalam kegiatan pengabdian yang dilaksanakan selama tiga hari dengan tiga metode, yaitu; ceramah, diskusi dan prakrek. Hasil kegiatan pengabdiaan ini meliputi: (1) terjalinnya kerja sama antar instansi atu lembaga (Prodi Pendidikan Olahraga FKIP UMS, Dispora, dan IPSI Kabuptaen Demak, (2) meningkatnya kompetensi pelatih tentang dasar ilmu kepelatihan dan perencanaan program latihan, dan (3) terlaksananya tugas pengabdian sebagai tindak lanjut hasil penelitian. Dapat disimpulkan, melalui kerjasama dan kolaborasi merupakan langkah strategis dalam upaya meningkatkan kompetensi pelatih pencak silat tentang ilmu kepelatihan olahraga berbasis sport science dan analisis kebutuhan disiplin olahraga (pencak silat). Terjalinnya kerjasama antar lembaga dapat ditindak lanjuti untuk pelaksaan program selanjutnya khususnya dalam upaya peningkatan kompetensi dan prestasi olahraga.
\end{abstract}

Kata kunci: kompetensi pelatih, sports science, tuntutan aktifitas, pencak silat

Abstract

This devotional activity has the aim of improving the competence of pencak silat trainers in Demak Regency in its assessment of the basic science of training and training program planning. This activity was carried out on the basis of cooperation between the service and partners (Dispora and IPSI) demak regency. A total of 30 participants participated in the service activities carried out for three days with three methods, namely; lectures, discussions and pre-reconds. The results of this training activity include: (1) the inter-agency cooperation between institutions (FKIP UMS Sports Education Program, Dispora, and IPSI Demak Regency,

(2) increasing the competence of trainers on the basis of training science and training program planning, and

(3) the implementation of devotional tasks as a follow-up to research results. It can be concluded, through cooperation and collaboration is a strategic step in an effort to improve the competence of coaches pencak silat about sports training science-based sports science and analysis of the needs of sports disciplines (pencak silat). Inter-agency cooperation can be followed up for the implementation of further programs, especially in efforts to improve competence and sports performance.

Keywords: coach competency, sports science, activity demands, pencak silat

Copyright (c) 2021 Nur Subekti, Muhad Fatoni, Rony Syaifullah

$\triangle$ Corresponding author

Address : Universitas Muhammadiyah Surakarta

Email : ns584@ums.ac.id

ISSN 2721-9224 (Media Cetak)

DOI $\quad$ : https://doi.org/10.31004/abdidas.v2i4.370

ISSN 2721- 9216 (Media Online) 
768 Meningkatkan Kompetensi Pelatih Pencak Silat Berbasis Sport Science Dan Tuntutan Aktifitas Pertandingan Pada Pelatih IPSI Se-Kabupaten Demak - Nur Subekti, Muhad Fatoni, Rony Syaifullah

DOI: https://doi.org/10.31004/abdidas.v2i4.370

\section{PENDAHULUAN}

Pencak silat yang merupakan salah satu warisan budaya bangsa Indonesia (Aziz et al., 2002), lahir dan berkembang hampir diseluruh wilayah di Indonesia termasuk yang ada di Kabupaten Demak. Tercatat ada 11 Perguruan Seni Beladiri pencak silat yang bergabung dibawah organisasi Ikatan Pencak Silat Indinesia (IPSI) Kabupaten Demak. Dengan kekuatan sebelas perguruan silat tersebut, seharusnya dapat memberikan kontribusi prestasi pada setiap ajang kejuaraan baik yang diselenggarakan internal maupun multievent baik dari tingkat daerah, nasional hingga internasional.

Namun, kenyataanya prestasi atlet pencak silat kabupaten Demak belum optimal dan masih sulit bersaing dnegand aerah lainnya. Menurut mitra, hal ini dikarenakan rendahnya tingkat pemahaman pelatih pencak silat tentang dasar-dasar ilmu kepelatihan. Kebanyakan pelatih pencak silat dalam melatih mengandalkan pengalaman mereka sebelumnya saat menjadi atlet, sehingga metode-metode latihan yang diterapkan masih bersifat klasikal dan tradisional. Selain itu, para pelatih pencak silat yang ada di Kabupaten Demak masih didominasi oleh pelatih-pelatih yang tidak memiliki latar belakang pendidikan di bidang keolahragaan. Minimnya SDM pelatih yang memiliki kompetensi keilmuan keolahragaan tentunya akan berpengaruh terhadap perkembangan kepelatihan berbasis ilmu pengetahuan dan teknologi (IPTEK) keolahragaan.

Peran pelatih sangatlah vital dalam proses pembinaan olahraga prestasi hingga mencapai keberhasilan dalam pertandingan. Pelatih dalam olahraga prestasi mempunyai tugas untuk membantu atlet untuk mencapai prestasi maksimal (Jenkins, 2006). Pelatih diakui keberhasilannya dalam melatih bila atlet binaannya bisa meraih kemenangan dan mendapatkan prestasi tinggi. Keberhasilan dan kegagalan atlet dalam suatu pertandingan dipengaruhi program latihan dari pelatih. Pendapat yang lain dikemukakan oleh (Short \& Short, 2005) pelatih adalah seorang yang profesional yang tugasnya membantu olahragawan dan tim dalam memperbaiki penampilan olahraganya.

Para pelatih yang aktif di kabupaten Demak masih cenderung menerapkan pelatihan bersifat klasikal atau tradisional. Program latihan belum direncanakan secara sistematis dan mengacu pada perkembangan ilmu keolahragaan. Selain itu, sesi-sesi latihan yang diterapkan belum mencerminkan pada tuntutan kebutuhan aktifitas pertandingan pencak silat. Para pelatih tidak memilii acuan norma dan skala, seperti apa gambaran status kondisi fisik dan keterampilan yang baik 
DOI: https://doi.org/10.31004/abdidas.v2i4.370

untuk proyeksi atlet professional. Hal ini merupakan sebuah ketertinggalan pengetahuan sebagai seorang pelatih, untuk itu harus segera ada evaluasi dan tindak lanjut untuk mengatasi ketertinggalan tersebut.

Dari hasil analisis situasi, disimpulkan bahwa pelatih pencak silat di Kabupaten Demak masih memiliki pemahaman yang rendah tentang ilmu kepelatihan dan implementasi sport science dalam kepelatihan olahraga prestasi. Selain itu, belum optimalnya prestasi atlet dilatar belakangi oleh penerapan sesi pelatihan belum merujuk pada kebutuhan dan tuntutan aktifitas teknis dan gerak waktu pertandingan pencak silat.

Sebagai upaya pemecahan masalah tersebut, melalui kerjasama antara pengabdi dengan Mitra (Dinas Pemuda dan Olahraga (DISPORA) dan Pengurus IPSI Kab Demak) merumuskan solusi yang dapat ditawarkan, yaitu kegiatan "Pelatihan Pelatih Pencak Silat Se-Kabupaten Demak Tahun 2021”. Kegiatan ini sekaligus menjadi sarana menjalankan tugas Tri Dharma Perguruan Tinggi (Pengabdian Kepada Masyarakat).

\section{METODE}

Sebagai upaya pemecahan masalah yang telah diidentifikasikan diatas, melalui kerjasama antara pengabdi dan Mitra (Dinas Pemuda dan Olahraga (DISPORA) dan
Pengurus IPSI Kab Demak) merumuskan solusi yang dapat ditawarkan, yaitu kegiatan Pelatihan Pelatih Pencak Silat Se-Kabupaten Demak Tahun 2021. Kegiatan ini sekaligus menjadi sarana menjalankan tugas Tri Dharma Perguruan Tinggi (Pengabdian Kepada Masyarakat).

Mengingat situasi saat ini masih dalam kondisi pandemi Covid-19, mitra penyelenggara kegiatan pelatihan pelatih telah berkoordinasi dan mendapat ijin resmi dari pihak Kepolisian serta Satgas Gugus Covid-19 Kabupaten Demak untuk melaksanakan kegiatan secara Off-Line. Kegiatan pelatihan pelatih pencak silat dilaksanakan pada tanggal 22 s.d 24 Juli 2021 bertempat di GOR Kelurahan Mangunjiwan, Demak. Berdasarkan surat undangan dari Dispora Kabupaten Demak, sebanyak 30 peserta dengan dasar surat tugas dari perguruan pencak silat, yang dijinkan mengikuti kegiatan pelatihan pelatih dengan tetap menerapkan prosedur protokol kesehatan. Kegiatan dilaksanakan dalam bentuk workshop dan pendampingan berbasis teori dan praktek. Adapun rincian umum jadwal kegiatan pelatihan disajikan pada Tabel 1 .

Materi-materi yang disampaikan tersebut, merupakan tindak lanjut dari hasil penelitian sebelumnya, dimana pengabdi melakukan tugas penelitian tentang "Analisis 
770 Meningkatkan Kompetensi Pelatih Pencak Silat Berbasis Sport Science Dan Tuntutan Aktifitas Pertandingan Pada Pelatih IPSI Se-Kabupaten Demak - Nur Subekti, Muhad Fatoni, Rony Syaifullah

DOI: https://doi.org/10.31004/abdidas.v2i4.370

Performa Teknik dan Gerak Waktu Pada Pertandingan Pencak Silat Level Elit”. Perkembangan ilmu kepelatihan menuntut para pelatih dapat mengembangan prosedur pelatihan dengan mempertimbangkan kebutuhan spesifik cabang olahraga (Lyle, 2005; Jones, 2006; ). Maka, melalui kegiatan pengabdian bidang kepelatihan olahraga berbasis sports science, menjadi suatu solusi awal dalam upaya meningkatkan kompetensi dan pemahaman pelatih pencak silat dalam proses menyusun program latihan dan implementasi dilapangan yang disesuaikan dengan tuntutan spesifik olahraga pencak silat.

Tabel 1. Jadwal Kegiatan Pelatihan Pencak Silat

\begin{tabular}{|l|l|l|}
\hline Hari/ Tanggal & \multicolumn{1}{|c|}{ Waktu } & \multicolumn{1}{c|}{ Materi Kegiatan } \\
\hline \multirow{4}{*}{$\begin{array}{l}\text { Senin } \\
\text { 22 Juni 2021 }\end{array}$} & $09.30-09.45$ & Materi Pengantar Ka.Dispora \\
\cline { 2 - 3 } & $09.45-12.00$ & Materi Pengantar Ketua IPSI Kab. Demak \\
\cline { 2 - 3 } & $12.00-13.00$ & Coffee Break - ISHOMA \\
\cline { 2 - 3 } & $13.00-14.30$ & Metodologi Kepelatihan \\
\cline { 2 - 3 } & $14.30-16.00$ & Ilmu Kepelatihan berbasis Sport Science \\
\hline \multirow{4}{*}{$\begin{array}{l}\text { Selasa } \\
\text { 23 Juni 2021 }\end{array}$} & $09.00-10.30$ & Teori Latihan Kondisi Fisik \\
\cline { 2 - 3 } & $10.30-12.00$ & Praktek Kondisi Fisik \\
\cline { 2 - 3 } & $12.00-13.00$ & Coffee Break - ISHOMA \\
\cline { 2 - 3 } & $13.00-14.30$ & Program Latihan \\
\cline { 2 - 3 } Rabu & $14.30-16.00$ & Periodisasi Latihan \\
\cline { 2 - 3 } & $09.00-10.30$ & Struktur Teknik dan Gerak Waktu pertandingan Pencak Silat \\
& & level elit \\
\cline { 2 - 3 } & $10.30-12.00$ & Perencanaan Program Latihan Pencak Silat \\
\cline { 2 - 3 } & $12.00-13.00$ & Coffee Break - ISHOMA \\
\cline { 2 - 3 } & $13.00-14.30$ & Evaluasi \\
\cline { 2 - 3 } & $14.30-16.00$ & Penutupan \\
\hline
\end{tabular}

Tujuan program pengabdian masyarakat melalui kegiatan pelatihan pelatih pencak silat ini, meninjau aspek kebutuhan dari masingmasing kepentingan, diantaranya sebagai berikut:

a. Mitra (DISPORA dan IPSI Kabupaten Demak): (1) Terlaksananya program kerja tahun 2021, (2) Meningkatnya indeks kompetensi pelatih, (3) Memperluas kerja sama

b. Peserta : (1) Meningkatnya pemahaman tentang teori kepelatihan dasar berbasis sport science, (2) Memiliki kemampuan dalam merencanakan program latihan berbasis tuntutan aktifitas pertandingan pecak silat

c. Institusi/lembaga/pengabdi/Dosen:

Terlaksananya tugas Tri Dharma Perguruan Tinggi (Pengabdian Kepda Masyarakat) hasil dari penelitian, (2) Pengembangan SDM dan IPTEK bidang keolahrgaan 
771 Meningkatkan Kompetensi Pelatih Pencak Silat Berbasis Sport Science Dan Tuntutan Aktifitas Pertandingan Pada Pelatih IPSI Se-Kabupaten Demak - Nur Subekti, Muhad Fatoni, Rony Syaifullah

DOI: https://doi.org/10.31004/abdidas.v2i4.370

\section{HASIL DAN PEMBAHASAN}

Adapun hasil yang dicapai pada kegiatan pengabdian ini, melalui kegiatan pelatihan pelatih pencak silat dapat penulis dekripsikan menjadi 3 hal, yaitu:

1. Terjalinnya kerja sama antar lembaga/intitusi, yaitu, Program Studi Pendidikan Olahraga FKIP UMS, Dispora Kabupaten Demak dan IPSI Kabupaten Demak

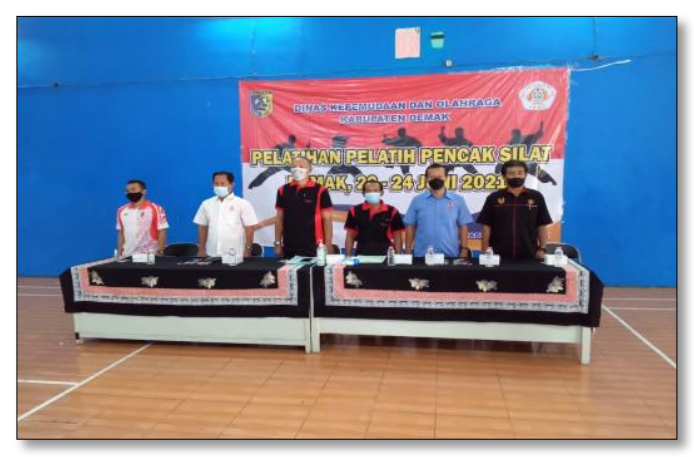

Gambar 1. Pembukaan Acara

2. Meningkatnya pemahanan dan kompetensi pelatih pencak silat Kabupaten Demak dalam teori ilmu kepelatihan dasar dan kemampuan menyusun program latihan jangka pendek.

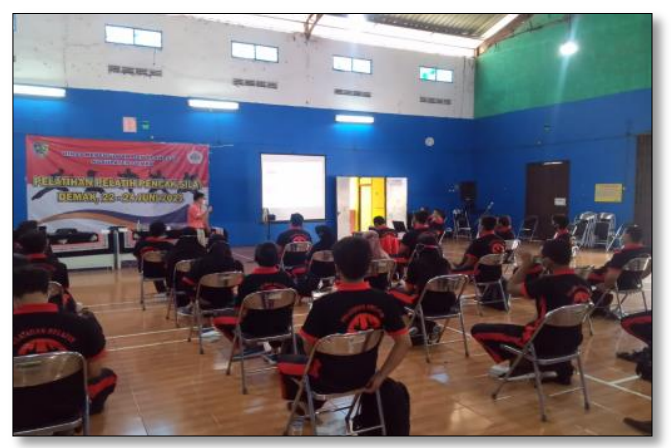

Gambar 2. Pemaparan teori ilmu kepelatihan berbasis sport science

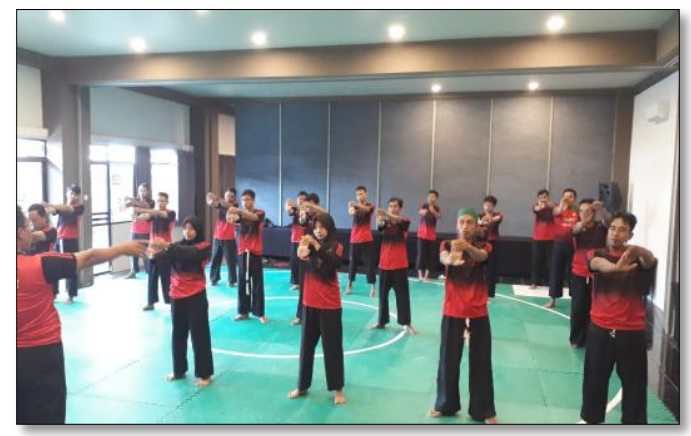

Gambar 3. Praktek latihan pencak silat

3. Terlaksananya tugas Tri Dharma Perguruan Tinggi bidang pengabdian kepada masyarakat, sebagai tindak lanjut hasil penelitian sebelumnya.

Indikator ketercapaian tersebut dapat dilihat dari luaran yang didapat dari kegiatan pelatihan pelatih pencak silat di Kabupaten Demak, diantaranya, yaitu: Surat Tugas, MOU (Memorandum of Understanding), Draft Periodisasi Latihan 1 tahun, dan Publikasi.

Selain itu, dalam setiap kegiatan perlu adanya evaluasi sebagai langkah memperoleh informasi penting dalam pelakssanaan kegiatan-kegiatan pengabdian selanjutnya. Hasil evaluasi kegiatan meliputi situasi pelaksanaan, kelebihan, kekurangan, dan peluang pengembangan (Syamsu \& Mashud, 2021).

\section{a. Situasi Pelaksanaan: Kegiatan} pengabdian dapat berjalan dengan lancar, panitia menunjukkan kesiapan dan peserta menyimak materi dari awal sampai akhir 
772 Meningkatkan Kompetensi Pelatih Pencak Silat Berbasis Sport Science Dan Tuntutan Aktifitas Pertandingan Pada Pelatih IPSI Se-Kabupaten Demak - Nur Subekti, Muhad Fatoni, Rony Syaifullah

DOI: https://doi.org/10.31004/abdidas.v2i4.370

dengan respon aktif khususnya dalam setiap sesi diskusi atua tanya jawab.

b. Kelebihan: dukungan moril dan meteriel yang diberikan oleh Mitra (Dispora Kabupaten Demak) secara optimal sehingga peserta merasa diberi kesempatan dalam mengembangan kometensi sebagai pelatih khsusunya pada cabang olahraga pencak silat.

c. Kekurangan: situasi saat ini masih dalam kondisi wabah pandemic covid 19, menjadi salah satu kendala kegiatan pelatihan. Sehingga kegiatan dalam tiga hari terlalu singkat dan kurang ideal.

d. Peluang Pengembangan: dengan terjalinnya kerja sama antar institusi atau lembaga, maka terbukanya peluang pengembangan dibidang ilmu keolahragaan khususnya dalam pembinaan, pelatihan dan prestasi olahraga.

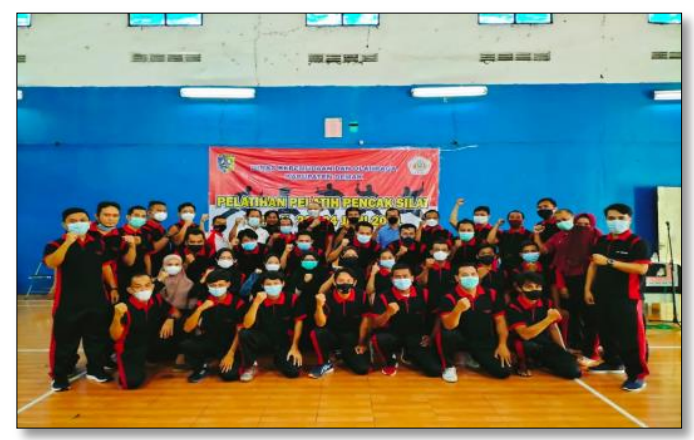

Gambar 4: Sesi penutupan dan foto bersama nara sumber dan peserta.
Mempertimbangkan hasil evaluasi tersebut, saran strategis yang dapat berikan sebagai tindak lanjut kegiatan ini, dengan adanya kerjasama dan kolaborasi yang terjalin dengan baik, kedepan perlu dilakukan kegiatan-kegiatan sejenis dalam rangka peningkatan kompetensi pelatih dan prestasi atlet pencak silat Kabupaten Demak. Tujuannya untuk memberikan pendampingan meningkatkan kemmpuan literasi pelatih dan atlet dalam bidang sport science dan sport coach, sehingga diharapkannya prestasi atlet pencak silat Kabupaten Demak dapat bersaing dan berkontribusi ditingkat nasional hingga internasional.

\section{SIMPULAN}

Adapun kesimpulan yang dapat dideskripsikan dalam kegiatan pengabdian kepada masyarakat ini, yaitu; kerjasama merupakan suatu langkah strategis dalam setiap kegiatan, khususnya dalam menjalankan tugas Tri Dharma Perguruan Tinggi. Adanya fungsi simbiosis mutualisme yang didapatkan dari masing-masing individu dan institusi atau lembaga. Melalui kolaborasi antar kepentingan, meningkatkan kompetensi seorang pelatih pencak silat di Kabupaten Demak lebih mudah tercapai. Dengan meningkatnya pemahaman pelatih tentang dasar ilmu kepelatihan dan perencanaan 
773 Meningkatkan Kompetensi Pelatih Pencak Silat Berbasis Sport Science Dan Tuntutan Aktifitas Pertandingan Pada Pelatih IPSI Se-Kabupaten Demak - Nur Subekti, Muhad Fatoni, Rony Syaifullah

DOI: https://doi.org/10.31004/abdidas.v2i4.370

program latihan yang berbasis dengan kemajuan ilmu pengetahuan, akan mudah bagi seorang pelatih dalam mengembangkan kompetensi secara mandiri maupun kelompok.

Hasil evaluasi kegiatan yang dilakukan memberikan saran strategis sebagai tindak lanjut dari kegiatan pengabdian ini, Dengan terjalinnya kerjasama antar intitusi atau lembaga ini, maka terbukanya peluang pengembangan selanjutnya khususnya dalam meningkatkan kompetensi pelatih dan prestasi atlet di level nasional hingga internasional melalui penguatan literasi bidang sport science dan sport coach. Sehingga para pelatih dan atlet pencak silat dapat ter-edukasi dengan baik, dan mampu mengembangkan potensipotensi yang dimiliki.

\section{UCAPAN TERIMA KASIH}

Ucapan terima kasih penulis sampaikan kepada Lembaga Penelitian dan Pengabdian Masyarakat (LPPM), Universitas Muhammadiyah Surakarta atas dukungan dan motivasi dalam pelaksanaan kegiatan pengabdian. Selain itu, terima kasih yang sebesar-besarnya kami haturkan kepada Mitra pengabdian (Dispora dan IPSI Kabupaten Demak) yang telah memberikan kesempatan kepada penulis dan menjadi mitra dalam pengabdian ini

\section{DAFTAR PUSTAKA}

Aziz, A. R., Tan, B., \& Teh, K. C. (2002). Physiological responses during matches and profile of elite pencak silat exponents. Journal of Sports Science and Medicine.

Jenkins, S. (2006). Extended Book Review: The Sports Coach as Educator: Reconceptualising Sports Coaching. SAGE Publications Sage UK: London, England.

Short, S. E., \& Short, M. W. (2005). Essay: Role of the coach in the coach-athlete relationship. The Lancet, 366, S29-S30.

Syamsu, S., \& Mashud, M. (2021). Pelatihan Pengelolaan Website Perguruan Tinggi. Jurnal Abdidas, 2(3), 700-704. 